\title{
PALESTINA DAN ISRAEL: Sejarah, Konflik dan Masa Depan
}

\author{
Misri A. Muchsin \\ Fakultas Adab dan Humaniora UIN Ar-Raniry \\ Jl. Nuruddin Ar-Raniry Kopelma Darussalam, Banda Aceh, Aceh, 23111 \\ e-mail: misrimuchsin@yahoo.com
}

\begin{abstract}
Abstrak: Palestina pada mulanya adalah bagian dari Daulah Islamiyah di bawah Turki 'Utsmani. Tetapi dengan dikuasai wilayah ini oleh Inggris (1917), seterusnya dicaplok sebagian besar (48 \%) oleh Yahudi, Palestina yang mayoritas penduduknya Muslim menjadi tidak merdeka. Tulisan ini bertujuan mengungkapkan perlawanan Muslim-Palestina terhadap Yahudi-Israel. Untuk maksud tersebut dimanfaatkan pendekatan dan analisis historis dengan library research dalam pengumpulan data. Dari studi ini ditemukan bahwa Zionis Israel menguasai Palestina karena mendapat sokongan dari sekutu utamanya yaitu Amerika Serikat, Inggris dan Prancis. Sementara Palestina berjuang sendiri, karena negara-negara Islam sekitarnya sudah pernah ingin membantu pada tahun 1968, tetapi mengalami kekalahan dalam peperangan enam hari. Akibatnya, Mesir, Suriah, Yordania dan Palestina lepas sebagian wilayahnya. Terakhir, Palestina semakin terpuruk, dan jika disahkan RUU Yahudi yang diajukan oleh Benyamin Netanyahu ke Parlemen Israel, Palestina dan Arab Islam akan semakin terdesak.
\end{abstract}

\begin{abstract}
Palestine and Israel: History, Conflict and the Future. At the beginning Palestine was a part of Daulah Islamiyah under the Turki Usmani, but because this area was dominated by England in 1917, then about 48 percent of it was annexed by Jews, Palestine with the Muslim majority became not independent. This writing aims at exploring the struggle Muslim-Palestine toward Jews-Israel. For this purpose, the use of historical analysis and library research approaches in collecting data were used. The findings from this research are that Zionist Israel dominated Palestine because of being supported by its main allies: America, English and France while Palestine struggle alone because the surrounding Islamic countries had ever wanted to help in 1968 but they were lost in a six-day war. Therefore, Egypt, Syria and Jordan and Palestine released a part of their area. Lately Palestine becomes worse and if the Jews constitution proposed by Benyamin Netayahu to the Israel Parliament, Palestine and Arab Islam will be strongly insisted.
\end{abstract}

Kata Kunci: Muslim, Palestina, Yahudi, Israel 


\section{Pendahuluan}

Sejarah menunjukkan bahwa orang-orang Yahudi atau Bani Israil adalah sekelompok kecil manusia di jagad Allah, sejak abad sebelum masehi hingga dewasa ini, dengan mitosmitosnya telah meresahkan dunia. Allah dengan firman-Nya menggambarkan perilaku jelek mereka dalam Q.S. al-Mâ'idah/5: 64, "mereka berbuat kerusakan di muka bumi dan Allah tidak menyukai orang-orang yang membuat kerusakan". ${ }^{1}$ Negara-bangsa Israelpenganut Yahudi (yang menjadi lawan konflik negara-bangsa Palestina-Muslim) sejak diproklamirkan pada tahun 1948, telah menunjukkan demikian eksistensinya di panggung sejarah dunia. Bagaimana tidak, Israel-Yahudi dengan "gaya perjuangannya" sudah menjadi pembicaraan publik dunia yang tidak habis-habis dan tidak hentinya. Karena itu bagaimana asal usul dan sasaran strategis yang diidealkan oleh Father founding mereka untuk dicapainya, menarik untuk ditelusuri lebih jauh. Pada sisi lain Palestina mulanya bagian dari Daulah Islamiyah di bawah Turki 'Utsmâni. Akan tetapi dengan dikuasai wilayah ini oleh Inggris (1917), seterusnya dicaplok sebagian besar (48 \%) oleh Yahudi-Israel, Palestina yang mayoritas penduduknya Muslim menjadi tidak merdeka.

Pada sisi lain lagi, di Israel telah digulirkan dan diajukan RUU Yahudi. ${ }^{2}$ Deklarasi Kemerdekaan dengan RUU dimaksud oleh Perdana Menteri Benjamin Netanyahu dan telah mendapat persetujuan kabinetnya pada tanggal 23 November 2014, dikatakan dalam rangka menegakkan hak individu semua warga Israel, khususnya yang Yahudi. Padahal harus diakui bahwa sekitar dua juta dari 8.2 juta jiwa warga negara Israel adalah terdiri dari orang-orang Arab-Muslim.

Tulisan ini bertujuan mengungkapkan perlawanan Muslim-Palestina terhadap YahudiIsrael. Untuk maksud tersebut dimanfaatkan pendekatan dan analisis historis dengan library research dalam pengumpulan data. Dengan pendekatan dan analisis historis serta kajian kepustakaan dalam pengumpulan data, diharapkan terungkap wujud perlawanan Muslim Palestina terhadap Yahudi Israel dalam sejarahnya. Pada sisi lain lagi dengan pendekatan sejarah tiga dimensi, akan dapat diprediksi masa depan perjuangan Muslim Palestina, termasukjika disahkan RUU Yahudi yang telah diajukan oleh Perdana Menteri Israel, Benjamin Netanyahu dan telah mendapat persetujuan kabinetnya pada tanggal 23 November 2014.

${ }^{1}$ Harus diakui pula bahwa di antara orang-orang Yahudi terdapat pula manusia pilihan di antara mereka walaupun amat sedikit. Allah memandang mereka sebagai kekasih-Nya. Mereka adalah orang-orang yang mendapat petunjuk, yang menyeru pada kemuliaan, kesalehan dan ketauhidan. Mereka itu adalah para nabi dan rasul Allah, seperti Ya'qub as., Yusuf as., Musa as., Harun as., Daud as., Sulaiman as., Zakaria as., Yahya as. dan 'Isa as. Begitu juga dengan Thalut walaupun bukan nabi dan rasul, tetapi Allah memujinya karena semangat keagamaan dan jihadnya. Mahir Ahmad Agha, Yahudi: Catatan Hitam Sejarah, terj. Yadi Indrayadi (Jakarta Timur: Qisthi Press, Juni 2005), h. 71-72.

${ }^{2}$ Isi RUU yang diajukan Benjamin Netanyahu menyangkut Hak individu warga Israel, hanya untuk orang Yahudi, mendapatkan hak nasional, hak menentukan nasib sendiri, bendera dan lagu kebangsaan. Lihat Serambi Indonesia, Kamis, 27 November 2014, h. 2. 
RUU dimaksud mereka sebagai komunitas minoritas, diasumsikan menjadi gelisah dan berada di ujung tanduk, karena ada kemungkinan akan didepak oleh pemerintahan Israel yang Yahudi, jika RUU perubahan nama negara Israel menjadi Negara Yahudi berhasil disahkan. ${ }^{3}$ RUU yang diajukan pemerintah Perdana Menteri Benjamin Netanyahu dan telah mendapat persetujuan kabinetnya dimaksud, mengantarkan Yahudi sebagai bangsa dan agama, memiliki semangat dan solidaritas baru di dunia internasional. Yahudi lebih luas maknanya dari Israel dan Ibrani. Hal itu karena istilah Yahudi selain disematkan kepada kaum Ibrani, juga bermakna dan dapat disematkan kepada orang-orang non-Ibarani yang memeluk agama Yahudi. ${ }^{4}$ Sementara orang-orang keturunan Arab yang Islam semakin terdesak dengan kebijakan-kebijakan mengikat dan akan mengurangi atau ada kemungkinan akan hilang haknya di negerinya sendiri sebelumnya.

\section{Negara Israel}

\section{Sejarah dan Nama Israel}

Dalam sejarah, nama Israel atau Bani Israel dikenal juga dengan Ibrani dan Yahudi. Dalam riwayat, sebutan Israel, orang atau Bani Israel (Israiliyin), adalah sebutan yang dinisbatkan kepada nama bapak mereka, yaitu Ya'qûb ibn Ishâq ibn Ibrâhîm as. Israel adalah kalimat yang terdiri dari dua kata, Isra yang artinya hamba atau teman dekat, dan el artinya Tuhan. Dengan demikian Israel artinya hamba Tuhan atau teman dekat Tuhan.

Kemudian mereka disebut Ibrani, karena dinisbatkan kepada nama Ibrâhîm as. Hal ini ditemukan dalam Kitab Kejadian, Ibrâhîm as disebut dengan nama "Ibrahim Sang Ibrani” atau maksudnya Ibrâhîm Sang Penyeberang, karena ia menyeberangi ('abara) sungai Eufrat dan sungai-sungai lainnya. Atau ada juga riwayat lain, mereka dinamakan kaum Ibrani karena dinisbatkan kepada Ibr, kakek kelima Ibrâhîm as. Akan tetapi para sejarawan sepakat bahwa penamaan Bani Israel dengan kaum Ibrani karena peristiwa penyeberangan Ibrâhîm as melintangi sungai Eufrat, yang diperkuat dengan ungkapan dalam kitab Joshua. ${ }^{5}$

Adapun dinamakan mereka dengan Yahudi, muncul ketika mereka bertaubat dari menyembah anak sapi. Mereka berkata, yang diabadikan oleh Allah dalam Q.S. al-A'râf/7: 156, "sesungguhnya kami kembali (bertaubat) kepada Engkau." Riwayat lain mereka dinamakan Yahudi karena mereka bergerak-gerak (yatahawwad) ketika membaca Taurat. Riwayat lain lagi bahwa mereka dinamakan Yahudi karena dinisbatkan kepada Yehuda, anak keempat Ya'qûb as., yang nama asli atau dasarnya Yehuza, pemimpin bagi sebelas anak Ya'qûb as. lainnya. ${ }^{6}$

${ }^{3}$ Serambi Indonesia, Kamis, 27 November 2014, h. 2.

${ }^{4}$ Agha, Yahudi: Catatan Hitam Sejarah, h. 12.

5Ibid., h. 10.

IIbid., h. 11-12. 
Menghidupkan dalam ingatan atau memori kolektif mereka bahwa asal usul nenek moyang mereka berasal dari keturunan seorang nabi, yaitu nabi Ya'qûb as. merupakan kemuliaan dan gengsi tersendiri dalam berhadapan dengan manusia lainnya. Karenanya sikap-sikap arogan yang ditunjukkan orang Israel dewasa ini kelihatan ada hubungan sedikit banyaknya dengan kesadaran-memori kolektif sejarah dan asal usul keturunan mereka.

\section{Negara Israel dalam Sejarah}

Jauh sebelum negara Israel Modern, di sana sudah pernah berdiri negara Israel pada zaman klasik, yaitu ketika negara Israel digagas dan dikembangkan oleh Syaul atau alQur'an menyebutnya dengan Thalut pada tahun 1025 SM. Ia menjadi pemimpin untuk seluruh Bani Israel yang bersuku-suku tersebut. Pada masanya banyak terjadi peperangan, seperti perang menakluk bangsa Amun di wilayah Timur Yordania; peperangan melawan bangsa Palestina yang ketika itu dipimpin oleh Goliath (al-Quran menyebutnya dengan raja Jalut). Konon rupanya dalam pasukan Syaul atau Thalut ikut serta Dâwûd as. yang ketika itu masih sangat muda dan ia pula yang berhasil membunuh Jalut dalam peperangan tersebut. Ketika itu, sebagian kecil Palestina dapat dikuasi pasukan Syaul/Thalut. ${ }^{7}$

Pasca Thalut, Dâwûd as. yang menjadi pemimpin Bani Israel. Palestina dengan demikian sudah berada di bawah kepemimpinan Dâwûd as.. Ia pula yang dianggap sebagai pendiri kerajaan Bani Israil di Palestina yang sesungguhnya. Pada masa pemerintahannya dakwah Tauhid menyebar ke seluruh Palestina yang dijuluki dengan "Tanah yang Diberkati". Keadilan, kedamaian dan kejujuran dijunjung tinggi, dan sebagai Nabiyullah, Dâwûd as. dengan kitab Zabur, dikarunia pula oleh Allah ilmu dan kebijaksanaan. Gunung dan burung-burung ikut bertasbih ketika ia membaca kitab Zabur dengan suaranya yang merdu dan khusyuk (Q.S. Shad/18-20). Dâwûd as. juga dikarunia mukjizat yang mencengangkan, yaitu di samping burung-hewan bertasbih bersamanya dan dapat pula melunakkan besi dengannya (Q.S. Sabâ'/34: 10). Daud meninggal dunia pada tahun 963 SM, dan menurut satu riwayat kuburannya terletak di gunung Zion, di tempat yang sekarang disebut dengan "al-Nabi Daud". ${ }^{8}$

Pasca Dâwûd as. meninggal, kepemimpinan Bani Israel diteruskan oleh anak/ putranya, Sulaiman as. yang berhasil menikahi puteri Fir'aun. Pada masa Sulaiman, Bani Israel mencapai puncak masa kedamaian dan kemakmurannya. Hal itu karena kerajaan tersebut sudah dibina sebelumnya oleh Daud dengan maksimal, sehingga tidak ada lagi rintangan politis apapun lagi. (Q.S. al-Nahl/16: 112; Q.S. al-Anbiyâ'/21: 78-82). Sulaiman membangun Kuil, yang memperkerjakan banyak ahli bangunan dan pemahat. Ia mengirim kapal mengharungi Samudera hingga ke selatan Spanyol. Pemerintahan Sulaiman

${ }^{7}$ Fuad Muhammad Shibel, Masalah Jahudi International, terj. Bustami A. Gani dan Chatibul Umam, (Djakarta: Bulan Bintang, 1970), h. 47-48.

${ }^{8}$ Agha, Yahudi: Catatan Hitam Sejarah, h. 36-37. 
berlangsung 40 tahun, dan selama itu pula Bani Israel mengalami kemakmuran dan kebahagiaan. Masa kepemimpinan Sulaiman yang berpusat di seluruh tanah Palestina, dianggap masa kejayaan industri dan teknologi canggih ukuran zamannya, di mana berhasil membangun bangunan yang indah, istana yang megah, kota-kota yang banyak dan megah serta benteng-benteng yang kokoh serta tentara yang terdiri dari pasukan jin, manusia dan burung-burung. ${ }^{9}$ Berkaitan dengan kesuksesan dan kejayaan Bani Israel di Palestina di bawah kepemimpinan Sulaiman as., Allah abadikan dalam Q.S. al-Naml/27: 17 dan 37; serta Q.S. al-A'râf/7: 27.

\section{Sejarah Bani Israel di Palestina Pasca-Nabi Sulaiman}

Pasca kepemimpinaan Dâwûd as. dan Sulaiman as. yang memerintah Palestina sekitar 80 tahun, maka sejak tahun 923 SM kerajaan Sulaiman tersebut terbelah menjadi dua negara dan antara keduanya saling bertikai. Pertama, Kerajaan Yehuza (Judah) di Selatan dengan ibukotanya Yerusalem (al-Quds). Negara/kerajaan ini dipimpin oleh Rehoboam ibn Sulaiman. Ia dibaiat dan didukung oleh dua suku Bani Israel, yaitu Yehuza dan Benyamin yang tinggal-berdomisili di wilayah Selatan dan di sekitar Yerusalem. Akan tetapi di daerah lain, Syakim atau Syakin tidak mau membaiatnya sebagai raja Bani Israel, karena kekasar-annya dan karena mengancam masyarakat di sana jika tidak mau membaiatnya. 10 suku Bani Israel yang ada di sana menolak membaiat dan malah mereka membaiat Rehoboam, dari suku Ephraem (salah satu suku Bani Israel) dan inilah kerajaan kedua Bani Israel yang berada di sebelah utara. Mereka menamakan kerajaan mereka dengan "Israel" dan menjadikan ibu kota kerajaan mereka berturut-turut di Syakim, Terzah dan terakhir di Samirah. Kerajaan ini diperkirakan hidup berkembang antara 923-722 SM dan menempati $72 \%$ wilayah Bani Israel. Kerajaan ini runtuh dan hilang setelah diserbu oleh Sargon II, raja Assyria, dengan rajanya yang terakhir adalah Hosea ibn Elah. Dengan demikian berakhirlah semua kerajaan Bani Israel dan raja Sargon II membuat kebijakan agar seluruh suku bani Israel diasingkaan dan ditempatkan di lembah sungai Eufrat dengan menunjukkan seorang gubernur Assyria untuk mereka. ${ }^{10}$

Begitu juga dengan nasib kerajaan Bani Israel di Selatan yaitu Yehuza, dengang ibukota Yerusalem (al-Quds), pada tahun 606 SM diserbu pula oleh Nebukhadnesar. Banyak penduduk yang terbunuh dalam serangan tersebut dan Rajanya yang terakhir di sana Yahwakin ibn Bawakim dan keluarganya juga diasingkan ke Babilonia, Irak. Akan tetapi di tempat pengasingan ini para bekas pimpinan kerajaan Yehuza memberontak pula, sehingga menyebabkan diserbu lagi ke Babilonia oleh Sargon II, raja Assyria, sehingga tahun 586 SM sudah berakhirlah semua kerajaan bani Israel. ${ }^{11}$

${ }^{9}$ Shibel, Masalah Jahudi International, h.14-16; dan Agha, Yahudi: Catatan Hitam Sejarah, h. 39.

${ }^{10}$ Agha, Yahudi: Catatan Hitam Sejarah, h. 41-45.

${ }^{11}$ Ibid., h. 48. 


\section{Yahudi di Palestina Pasca-Kehancuran I}

Disebutkan bahwa tahun 586 SM adalah tahun kehancuran dan kelenyapan pertama kerajaan-kerajaan Bani Israel di Palestina pada tangan Nebukhadnesar. Kemudian setelah Nebukhadnesar, Palestina dikuasai oleh beberapa kerajaan dari luar, yaitu kerajaan Babilonia antara tahun 586-538 SM, kerajaan Persia antara 538-330 SM, kerajaan Yunani antara tahun 330-200 SM, Dinasti Seleucid antara tahun 200-167 SM, Dinasti Seleucid dan Maccabee antara tahun 167-63 SM, dan Imperium Romawi antara tahun 63 SM sampai 638 M. ${ }^{12}$

Pada masa Imperium Romawi berkuasa, terutama masa Kaisar Romawi Konstantin yang sudah memeluk Nasrani pada tahun 325 M, Palestina umumnya sudah dinasranikan. Di al-Quds Yerusalem dibangun gereja Makam Suci sebagai gereja teragung. Di puncak gunung Zaitun dibangun pula gereja Langit dan di kota Bethlehem dibangun pula gereja Kiamat. Adapun orang-orang Yahudi ketika itu terutama para pedagangnya sudah menyebar ke negara-negara Eropa. Adapun di Palestina sendiri orang Yahudi terdesak dengan berkembangnya Nasrani yang didukung langsung pula oleh penguasanya yang Nasrani. Karenanya, Yahudi dimana pun mereka berada, termasuk di Eropa tetap menghalanghalangi orang Nasrani. Hal itu karena Nasrani yang umat Nabi Isa as. membawa agama Tauhid dan terdesak keberadaan ajaran Yahudi yang sudah menyembah patung. Orang Yahudi atau Bani Israel mendustakan nabi terakhir mereka dengan menuduhnya melakukan sihir dan berusaha membunuh Nabi Isa AS. Bani Israel melakukan itu karena diasumsikan bahwa Nasrani telah menghancurkan prinsip-prinsip ketuhanan dan syariat Talmud tentang keagungan Yahudi sebagai bangsa pilihan Allah. ${ }^{13}$

Pertentangan orang Yahudi dengan Nasrani tidak lagi di sekitar Palestina, Irak dan Timur Tengah umumnya, tetapi sudah pernah merambah-melebar ke seluruh Eropa dan malah ke benua Amerika, karena Nasrani juga mulai berkembang luas di sana. Hanya saja Sifat Yahudi yang ingin memonopoli, terutama perdagangan, maka sejumlah komoditas, seperti gandum, wol, emas dan perak dikuasainya. Dengan begitu mereka bisa menguasai pasar dan malah dapat mengontrol ekonomi negara dunia pada umumnya. Mereka bertindak rentenir, yaitu meminjamkan uang kepada orang Nasrani dengan bunga yang tinggi. Keinginan memonopoli ini pula kemudian yang menyebabkan orang-orang Eropa (yang Nasrani utamanya), membenci orang-orang Yahudi di manapun mereka berada. Klimaksnya adalah tindakan Nazi pada awal abad 20 M. ${ }^{14}$

Pertentangan Nasrani-Yahudi bertambah meningkat dari waktu ke waktu. Satu hal yang menarik, walaupun upaya Yahudi untuk menghalang-halangi pergerakan Nasrani, nama agama yang yang lebih popular sebutannya dengan Kristen ini terus menunjukkan perkembangannya di Eropa yang umumnya ketika itu masih Pagan atau Pelbegu. Hal

\footnotetext{
${ }^{12}$ Shibel, Masalah Jahudi International, h. 17; Agha, Yahudi: Catatan Hitam Sejarah, h. 49.

${ }^{13}$ Agha, Yahudi: Catatan Hitam Sejarah, h. 59.

${ }^{14}$ Ibid., h. 60-61; Shibel, Masalah Jahudi International, h. 72-73.
} 
ini menyebabkan penganut Yahudi bertambah kesal karena tidak rela Kristen yang menyeru kasih sayang, persamaan, cinta kasih dan persaudaraan tersebut mendapat momentum perkembangannya yang mudah dan pesat di kalangan bangsa-bangsa Eropa. Karenanya, orang-orang Yahudi tidak tinggal diam, kecuali itu mencari jurus-jurus licik, seperti mempengaruhi penguasa Eropa yang pagan, Markus Urulius, kaisar Romawi pengganti pamannya (Antonius Mulia) yang amat kesohor. Seorang Rabi Yahudi sukses membisik dan menakut-nakuti Markus Urulius yang pagan dan bodoh itu dengan mengatakan bahwa orang-orang Nasrani mengindap penyakit menular yang membahayakan rakyat. Karenanya, Markus Urulius sebagai penguasa Roma yang berhasil terperdaya dengan bisikan fitnah tersebut mengeluarkan perintah untuk membunuh semua penduduk Roma yang beragama Nasrani. ${ }^{15}$

Dapat dipahami bahwa penderitaan yang dialami oleh Kristen atau Nasrani pada periode awal amatlah berat, akibat kebijakan penguasanya yang termakan issue fitnah dari orang-orang Yahudi. Keadaan yang tidak menguntungkan Nasrani berlangsung hingga abad keempat masehi. Akan tetapi dengan masuknya Nasrani Kaisar Konstantin, maka nasib dan keadaan orang Nasrani segera berubah dan mendapat angin segar. Hanya saja orang-orang Yahudi tidak juga berhenti dalam provokasinya, bahwa mereka melalui perdagangan yang dikuasainya, terutama beberapa komoditas, seperti wol, sutra, gandum, emas dan perak, mereka ingin mengontrol kehidupan ekonomi negara secara fokus di mana mereka berdomisili. Tidak jarang mereka menciptakan krisis di negara tersebut, untuk menciptakan ketergantungan negara dan rakyatnya pada mereka yang memonopoli perdagangan dan kehidupan ekonomi satu Negara. Mereka menimbun mata uang emas dan perak, kemudian memonopolinya; serta meminjamkan uang kepada orang Nasrani dengan bunga yang melangit, sehingga julukan rentenir amat popular kepada orang Yahudi dimana pun mereka berada. ${ }^{16}$

\section{Kelompok atau Sekte dalam Agama Yahudi}

Para ahli mengelompokkan Yahudi dalam tiga kelompok besar, yaitu Ashkenazim, Sefardim, dan Syarqiyin. ${ }^{17}$ Ketiganya masih eksis dan berkembang hingga dewasa ini di berbagai benua-belahan dunia.

Pertama, Ashkenazim, adalah kelompok Yahudi yangdisebut juga dengan Yahudi Khazar dan dinisbatkan kepada Yahudi Jerman, atau Yahudi keturunan Jerman. Mereka hidup di negari-negeri yang berbahasa Jerman umumnya, yang hidup berkembang pada Abad Pertengahan, khususnya sejak abad 13 M. Akan tetapi seiring dengan perkembangan

${ }^{15}$ Ibid., h. 60 . h. 61 .

${ }^{16}$ Shibel, Masalah Jahudi International, h. 70-73; dan Agha, Yahudi: Catatan Hitam Sejarah, ${ }^{17}$ Ibid., h. 70-73; Agha, Yahudi: Catatan Hitam Sejarah, h. 66-70. 
zaman, negara-bangsa dan peluang yang dimanfaatkan, pada gilirannya mereka menyebar ke negeri-negeri Timur dan Barat. Mereka yang pada mulanya berbahasa Jerman, dengan menyisipi beberapa kosa kota Ibrani dan bahasa asing lainnya menetapkan dan melestarikan bahasa mereka yang dinamakan dengan Viadish. Mereka umumnya menetap di Inggris, utara Prancis, serta sebagian wilayah Austria yang dihuni suku-suku Slavik.

Kedua, Sefardim, adalah orang-orang Yahudi yang berpindah ke Semenanjung IberiaSpanyol, khususnya setelah wilayah itu ditaklukkan oleh kaum Muslim sejak tahun 711 M. Mereka menggunakan bahasa Spanyol sebagai bahasa sehari-harinya meng-gantikan bahasa Arab. Pada masa pemerintahan Islam di sana, orang-orang Yahudi berkembang pesat, tetapi setelah pemerintahan Islam runtuh di sana dan digantikan oleh pemerintahan Nasrani yang Katolik, orang-orang Yahudi ikut terdesak dan tertekan. Karenannya, tidak sedikit mereka yang berpura-pura masuk Kristen atau Nasrani Marony khususnya, walaupun padahal mereka tetap menjalankan ritual keagamaan Yahudi secara sembunyi-sembunyi. Kondisi yang demikian tentu tidak menguntungkan, dan karenanya mereka umumnya berimigrasi ke wilayah utara Eropa, khususnya ke Jerman dan daerah dataran-dataran rendah sekitarnya. Mereka bergabung dan bersatu dengan sekte Yahudi Ashkenazim, walaupun pada awalnya saling mengklaim masing-masing menyatakan kelompoknya yang paling mulia. Hanya saja dalam rangka menghadapi tekanan Eropa umumnya dari yang Kristen, sejak abad 16-18 M, mereka bersatu dan kemudian kebanyakan mereka berpindah pula ke Slanik di Yunani.

Ketiga, Syarqiyin, mereka adalah kelompok Yahudi yang terusir dan meninggalkan tanah Palestina. Mereka menyebar di Irak, Iran, Afghanistan, Delta Mesir Barat dan Utara Afrika (Maroko dan sekitarnya). Mereka Yahudi yang menggunakan bahasa setempat di mana mereka berdomisili, walaupun bahasa tradisionalnya tetap mereka pertahankan. Ketika pertengahan abad ke 20 M, ramai-ramai Yahudi kembali ke Palestina, terutama dalam peperangan Islam-Yahudi 1960-an. Kelompok Yahudi Syarqiyin ikut juga kembali ke Palestina dan setelah berada di sana mereka disebut Yahudi Separdim dan mereka memiliki Rabi sendiri.

Dalam perkembangan sejarahnya, penggunaan istilah Yahudi Ashkenazim adalah Yahudi Barat dari Eropa dan Amerika yang berpindah ke Palestina. Padahal banyak di antara mereka yang berasal dari kelompok Yahudi Sefardim. Akibatnya neraca sosial di kalangan Yahudi juga terbalik. Status Yahudi Ashkenazim naik statusnya dan Sefardim turun statusnya. Tidak hanya itu Ashkenazim menjadi pemegang kendali politik di negara Israel hingga dewasa ini. Dengan demikian, masyarakat Israel dewasa ini didominasi oleh kebudayaan dan orang Yahudi Barat-Ashkenazim, termasuk yang menduduki posisi-posisi strategis dalam negara-pemerintahan Israel. Adapun kelompok Yahudi Sefardim atau yang lazim disebut dengan kelompok Yahudi Timur, dalam pandangan orang Yahudi adalah kelompok Yahudi kelas bawah, satu tingkat di atas warga negara Israel yang keturunan Arab. Kemudian 
para pendatang lainnya, termasuk yang Kristen yang ada di Israel merupakan kelompok/ kelas keempat. ${ }^{18}$

Perihal kondisi memprihatinkan eksistensi Yahudi Timur-Sefardim umumnya dan Yahudi Sudan-Ethiopia yang berpindah ke Israel sejak 14-20 tahun lalu, seperti diberitakan oleh majalah Falestin al-Muslimah, mereka hidup pada lapisan terbawah (kelima). Jadi di bawah Arab-Islam (lapisan ketiga) dan Kristen lainnya bertengger di lapisan keempat. Begitu juga Yahudi yang berpindah dari Irak dan Mesir, mendapatkan perlakuan diskriminatif dan pelecehan-pelecehan dari Yahudi Barat Ashkenazim yang menempati posisi dan peran strategis dalam menentukan kebijakan politik, ekonomi, sosial dan administrasi di Israel. Mereka merupakan pemegang pimpinan di Israel dan sekaligus ekstremis Zionisme inter-national yang memiliki sarana jaringan IT yang mampu merombak tatanan IT dunia. Mereka yang punya Yahoo, Google dan dengan situs-situs porno yang dapat menambah kekayaan Israel Yahudi secara pasti.

\section{Perebutan Tanah Palestina dalam Sejarah}

Harus diakui bahwa Turki 'Utsmâni menguasai Tanah Palestina dalam waktu yang lama, yaitu sejak wilayah ini dan Timur Tengah umumnya berada di bawah kekuasaannya yang tidak kurang dalam tiga abad. Palestina baru berpindah tangan dari Turki Usmani ke Imperialisme Inggris pada tahun 1917, akibat dari kekalahan Turki Usmani dalam perang. Hanya saja seolah Palestina baru berpindah tangan dari orang Arab-Islam kepada orang-orang Yahudi setelah mereka mendeklarasikan Israel sebagai satu negara merdeka pada tanggal 15 Mei 1948.

Dalam rentang tahun 1948-1968, Israel sudah cukup eksis dan kuat di Palestina serta di sekitar Timur Tengah umumnya. Buktinya dalam peperangan pada 1967, beberapa negara Islam yang terlibat, seperti Mesir, Yordania, Suriah, Bairut, Arab Saudi, Irak dan Palestina sendiri berhadapan dengan Israel, tetapi dalam kenyataannya umat Islam dengan negara masing-masingnya tidak dapat berbuat banyak, kecuali itu, Israel menjadi sahnya berdiri sebagai satu negara merdeka dari hasil caplokan beberapa negara Islam yang disebut di atas.

Pertanyaannya, bagaimana bisa berdiri Israel sebagai satu Negara merdeka, di satu wilayah kekuasaan sah Turki Usmani? Hal ini tidak lepas dari dukungan dan keinginan beberapa negara Barat, dan Inggris khususnya. Orang-orang Yahudi dalam sejarahnya sampai pada zaman modern menghalalkan segala cara demi terwujudnya rencana dan target kekayaan dan politiknya. ${ }^{19}$ Di Inggris, Eropa sebelumnya, tepatnya tahun 1897, sudah

\footnotetext{
${ }^{18}$ Agha, Yahudi: Catatan Hitam Sejarah, h. 67-68.

${ }^{19}$ Mereka tidak segan dan malu sedikit pun menjual dan melacur gadis-gadis perawan bangsanya yang diperuntuk orang asing, terutama para diplomat asing dengan konpensasi akan menemukan
} 
dibentuk satu organisasi yang bernama Judenstat atau kemudian lebih popular State of Israel. Organisasi ini berideologi seperti makna zionisme (zion artinya batu atau merujuk ke haikal Sulaiman yang ada di al-Quds) untuk dijadikan sentra negara Yahudi.

\section{Estimasi Yahudi sebagai Negara Merdeka di Palestina}

Pendudukan Yahudi di Palestina dan berakhir dengan berdirinya negara Isreal merdeka, sebenarnya berawal dari berdirinya organisasi Zionis Dunia (World Zionist Organization) pada tahun 1897 M. Organisasi ini mengagendakan yang utama adalah pendirian Negara bagi bangsa Yahudi di tanah Palestina. Rencana strategis Zionis ini diprakarsai oleh pelobi top Zionis (Chief Zionist Negotiator), Dr. C. Wheizmann dan mendapat dukungan dari Zionist British atau Britain. Di bawah komandonya, Zionist berhasrat untuk mencapai agenda utamanya yaitu berdiri negara Yahudi di Tanah Palestina. Untuk mencapai agenda utamanya, menurut Mohd. Roslan Mohd. Nor ada empat hal yang diprogramkan. Pertama, melakukan promosi, mengikut kesesuaian, tentang penjajahan Palestin melalui system pertanian Yaahudi dan pekerja industri. Kedua, mewujudkan organisasi dan kerjasama dengan seluruh tentara Yahudi dengan cara menguasai institusi, tempatan atau antar bangsa dengan mengikut undang-undang setiap negara. Ketiga, menguatkan dan meningkatkan kesadaran dan sentimen kebangsaan Yahudi. Keempat, melakukan persediaan untuk mendapatkan pengiktirafan kerajaan, jika perlu, untuk menjalankan tujuan serta agenda zionis. ${ }^{20}$

Empat program inilah yang dijadikan landasan perjuangan Yahudi di Palestina. Kemudian dengan empat hal yang diprogramkan ini juga mereka mendapat simpati dan empati dari Yahudi dunia pada umumnya, dan sokongan dari Inggris atau Britania Raya pada khususnya. Hal yang disebutkan terakhir yaitu dukungan dari Inggris seperti terlihat dalam Deklarasi Balfour yang dikeluarkan pada 2 November $1917 .{ }^{21}$ Perjanjian Inggris dalam wujud deklarasinya merupakan modal penting bagi Yahudi untuk mewujudkan bagi mereka satu negara merdeka di tanah Palestina. Yahudi dengan deklarasi Balfour menyemangati Yahudi di seluruh dunia, terutama di Eropa Timur untuk menyokong upaya mewujudkan bagi Yahudi di Palestina memiliki negara merdeka, yang diberi nama kemudian dengan negara Israel.

Dalam sejarah Palestina modern, yang notabene adalah Arab Muslim umumnya,

informasi penting dunia dari diplomat tersebut. Lihat lebih lengkap Abdullah al-Thail, Yahudi Sang Penghancur Dunia, terj. Misbah Em Madjidy (Jakarta Timur: Mihrab, 2008)

${ }^{20}$ Mohd. Roslan Mohd. Nor, "Konflik Israel-Palestin dari Aspek Sejarah Modern dan Langkah Pembebasan dari Cengkaman Zionis," dalam Journal of Tamaddun, Desember 2010, h. 75.

${ }^{21}$ Deklarasi Balfour isinya adalah His Majesty's Government view with favour the establishment in Palestine of a national home for the Jewish people, and will use their best endeavours to facilitate the achievement of this object, it being clearly understood that nothing shall be done which may prejudice the civil and religious rights of existing non-Jewish communities in Palestine, or the right and political status enjoyed by Jews in any other country. Mohd. Roslan Mohd. Nor, "Konflik IsraelPalestin," h. 76. 
telah jatuh ke tangan Inggris pada tahun 1917, sesuai dengan kekalahan Turki Usmani di negeri ini dan Liga Bangsa-bangsa (League of Nations) sebelum PBB atau United Nation memberi mandat kepada Inggris untuk mengurus Palestina. Umat Islam dengan tokohtokoh ulamanya seperti Haji Husaini (mufti Palestina) selalu saja berjuang ingin melepaskan diri dari cengkraman penjajahan Inggris yang mengistimewakan dan lembaga Zionis yang ada di Eropa bernama Judenstat atau kemudian lebih popular State of Israel. Kenyataan ini telah memacu orang-orang Yahudi masuk-datang ke Palestina ketika mereka amat tertekan dan ditindas pada umumnya di Eropa, di Eropa Timur khususnya. Inilah awal petaka dan sumber konflik Islam-Yahudi di Palestina. Lebih-lebih setelah State of Israel yang diketuai oleh Theodor Herzl, dijadikan bahan utama dalam rencana mendirikan negara Israel.

Sebagian ahli menyebutkan bahwa mengidealkan dan mewujudkan negara bagi orang Yahudi di tanah Palestina dengan dalih bahwa orang Yahudi mempunyai hubungan sejarah lama dengan istilah yang digunakan historic right atau historic title, tidaklah ada asas dalam perundang-undangan dan tidak pula dasar hukum yang nyata. Cattan menyebutkan bahwa undang-undang antar bangsa tidak membenarkan yang demikian dan juga mengaitkan dengan sejarah lama (historic title atau historic right) tidak benar. Kedua istilah ini lebih untuk mendapatkan hak kawasan (territory) satu negara yang berkaitan dengan perairan (maritime). ${ }^{22}$

Jelaslah bahwa berdasarkan undang-undang antar bangsa tidak membolehkan membangun satu negara atas dasar karena mempunyai ikatan dengan sejarah semata. Orang Yahudi yang membangun negara Israel di Palestina jelas tidak memiliki dasar hukum dan dasar argument. Karena itu, Yahudi dalam dan setelah mewujudkan negara Israel segera melakukan perampasan, menduduki dan menghalau penduduk Palestina yang memang Muslim dari tanah negeri mereka. Israel membunuh dengan membabi buta penduduk Palestina Muslim yang tidak bersalah, sebagaimana yang terjadi dalam peristiwa Deir Yasin pada tahun 1948. Tentara atau Irgun Yahudi-Israel telah membunuh dan menyiksa laki dan perempuan dewasa, remaja dan bayi, sekalipun secara keji. Semua itu untuk menimbul kesan kekejaman dan keganasan mereka, sehingga dengan demikian diharapkan Muslim Palestina timbul rasa takut dan akan meninggalkan tanah kelahiran mereka, sehingga dengan demikian melempangkan jalan bagi pendudukan Yahudi-Israel di Tanah Palestina, Yerusalem khususnya. ${ }^{23}$

Realitas yang lebih jelek bagi umat Islam Palestina adalah setelah Israel menang dalam perang enam hari pada bulan Juni 1967. Yerusalem Timur dikuasai, Masjid al-Aqsa dan Bayt al-Maqdis dikuasai secara politik dan perundang-undangan. Serangan dan pembunuhan keji dilakukan oleh Israel terhadap umat Islam Palestina secara terus menerus.

\footnotetext{
${ }^{22}$ Henry Cattan, Palestine and International Law (London: Longman, 1973), h. v.

${ }^{23}$ Nor, "Konflik Israel-Palestin," h. 78.
} 
Pada 21 Agustus 1969 Masjid al-Aqsa dibakar, sehingga sebagiannya, termasuk mimbar yang sudah berusia 1000 tahun musnah.

Memasuki tahun 1980 Muslim Palestina bangkit bersatu ingin membebaskan dan membela diri dari cengkraman Israel. Gerakan mereka terkenal dengan nama Intifadah I yang berlangsung hingga tahun 1993. Gerakan pembebasan Muslim ini reda setelah adanya perjanjian Oslo menuntut perdamaian dan juga rupanya membolehkan rakyat Israel hidup bebas di Palestina. Akan tetapi walaupun sudah ada perjanjian Oslo, namun Israel terus menerus menindas rakyat Muslim Palestina. Pada akhir tahun 2008-22 Januari 2009 serangan mereka begitu gencar melancarkan bom, sehingga meng-hancurkan sekolah, rumah ibadah dan sarana umum di samping rumah hunian penduduk. Mereka menyerang dengan alasan untuk memerangi Hamas yang memerintah Gaza sejak Maret 2006. Israel menganggap Hamas sebagai golongan teroris yang harus diperangi, dan melobi negara-negara Barat untuk tidak memberikan bantuan keuangan kepada Hamas.

\section{Negara Palestina}

Jauh sebelum negara Israel berdiri di Timur Tengah, orang-orang Yahudi selalu saja berhasrat kuat untuk menduduki tanah Palestina. Berbagai daya upaya diprogramkan, misalnya perjanjian Balfour di Inggris, berupaya keras membeli tanah di Palestina dan usaha lainnya sebagai provokasi. Seiring dengan itu pula masyarakat Islam dari berbagai kalangan selalu saja memegang dasar yang harus dijalankan di Palestina. Mereka mengidealkan dan malah menuntut selalu penghapusan janji Balfour yang penuh dengan kezaliman, ketidakadilan terhadap hak-hak bangsa Palestina; penghentian imigrasi Yahudi; penghentian penjualan tanah Kepada Yahudi; pendirian pemerintahan nasional Palestina dengan dipilih oleh parlemen (majlis Tasyri'i) yang menjadi penjelmaan keinginan hakiki masyarakat; dan masuk dalam negosiasi dengan Inggris untuk membuat kesepakatan yang akhirnya dapat memerdekakan Palestina. ${ }^{24}$

Kejatuhan umat Islam di Palestina di satu sisi dan kesuksesan Yahudi mencapai negara merdekanya, Israel yang dibangun di atas persakitan umat Islam di Palestina, dan sekitarnya, sebenarnya bukanlah mutlak karena kehebatan dan kesuksesan Yahudi menggalang kekuatan, dukungan dan lobi mereka, tetapi karena kelemahan pertahanan umat Islam di Palestina di bawah komando Turki 'Utsmâni pada memasuki awal abad ke-20 begitu nyata. Pasukan Turki 'Utsmâni tidak dapat berbuat banyak dalam menghadapi agresi negara-negara Eropa, yang simpulnya adalah Yahudi di dalamnya. Faktor lain karena umat Islam tidak berupaya mempertahankan persatuan (Pan-Islamisme) untuk seluruh umat Islam, tetapi sebaliknya umat Islam sudah termakan isu konsep negara bangsa

${ }^{24}$ Muhsin Muhammad Shaleh, Palestina: Sejarah, Perkembangan dan Konspirasi, terj. Tim Comes (Jakarta: Gema Insani Press, 2002), h. 50. 
(nation state) yang dipopulerkan Barat, terutama dari Prancis sebagai imbas dari revolusinya yang amat terkenal telah merobah tatanan dan peta politik negara bangsa dunia.

Hal yang disebutkan terakhir buktinya adalah bahwa di penghujung abad 19, dan hingga awal memasuki abad 20, umat Islam amat tergiur dengan kemerdekaan negerinya masing-masing. Hal ini tentu bukti kesuksesan Barat dengan politik negara bangsanya, yang terkenal dengan semboyan misalnya Mesir untuk Mesir, Mesir bukan untuk Turki". Ini awal terpecah belah umat Islam, yang tidak lagi menjunjung tinggi nilai khilafah yang sudah diwariskan Nabi dan Khulaur-Rasyidin sebelumnya. Dengan kesuksesan provokasi Barat dengan politik negara bangsa demikian, maka Turki Usmani sebagai pemegang legitimasi khilafah otomatis mendapat serangan dari luar dan dari dalam. Dari luar adalah dari Barat sendiri yang ingin menjarah sebagian wilayah kekuasaannya, sementara dari dalam adalah dari umat Islam sendiri yang sudah amat tertarik untuk melepaskan diri dari kepemimpinan dan kekhalifahan Turki 'Utsmâni. Dua hal inilah yang membawa petaka bagi umat Islam dalam upaya mempertahan diri dari serangan Barat, termasuk Palestina dari pendudukan Yahudi yang "pulang kampung" dari perantauan lama keturunan mereka di berbagai negara Eropa dan Amerika.

Upaya Muslim Palestina mempertahankan diri dan malah ingin melepaskan diri dari cengkraman negara Israel yang Yahudi tersebut, diketahui dengan muncul gerakan, organisasi dan tokoh-tokoh pejuangnya yang silih berganti. Fatah, Hamas dan PLO (Palestin Liberation Organisation) adalah gerakan rakyat Palestina dan sebagai wadah perjuangan mereka untuk melawan Israel yang terkutuk. Di samping itu untuk membebaskan Palestina dari cengkraman penjajahan Yahudi-Israel, menurut Roslan, perlu disadarkan umat Islam umumnya dan rakyat Palestina khususnya bahwa pentingnya Bait al-Maqdis dalam Islam, adalah satu di antara tiga tempat suci yang harus diziarahi, yaitu di samping Masjidilharam dan Masjidnabawi. ${ }^{25}$

Upaya pembebasan Palestina dari Israel sudah dipikirkan pada level negara-negara Arab, seperti Yordania, Mesir, Arab Saudi, Suriah. Pemikiran dan upaya tersebut sudah sampai pada kesimpulan perjuangan bersama untuk membebaskan Palestina dari pendudukan Israel sejak tahun 1948. Semua negara di atas sudah bersiap untuk menggempur dan Mesir sudah menutup pesisir Laut Tengah (Madhaiq Tiran) serta meminta pengawas perbatasan PBB untuk meninggalkan wilayahnya. Akan tetapi sebelum pasukan Liga Arab itu bergerak, tepatnya pada 5 Juni 1967, Israel yang didukung oleh Inggris dan Prancis lebih dahulu membombardir pesawat-pesawat tempur Mesir, Yordania dan Suriah yang masih parkir di bandaranya masing-masing. Hal ini sesuatu yang tidak diduga samasekali, sehingga akibatnya Israel lebih leluasa menyerang ke seluruh penjuru dan negara-negara tersebut. $80 \%$ persenjataan Mesir hancur dalam peristiwa tersebut. Israel dalam waktu enam hari saja berhasil menjajah wilayah Palestina yang masih tersisa yaitu Tepi Barat $5878 \mathrm{~km}$ dan

${ }^{25}$ Nor, “Konflik Israel-Palestin,” h. 78. 
Gaza 363 km; Gurun Sinai milik Mesir 61198 km; dan dataran tinggi Golan 1150 km2. Tidak hanya itu Pasukan tempur Yahudi tersebut berhasil memasuki wilayah al-Quds dan Masjidilaqsha, sambil bernyanyi: musy-musy dan apel... agama Muhammad berpaling dan tunggang-langgang, Muhammad telah mati... dengan meninggalkan kaum wanita". Mereka juga berteriak, "ayo kita balas dendam (kekalahan) di Khaibar...". ${ }^{26}$ Realitas historis di atas amat menyakitkan hati umat Islam yang menghayati dan memiliki rasa solidaritas keislamannya.

\section{Gerakan Fatah}

Dalam upaya pembebasan Palestina dari Israel, pemuda palestina yang ada di luar di negara-negara Timur Tengah ingin berjuang melalui oranisasi, dan organisasi yang muncul pertama dari kalangan Arab-Muslim Palestina adalah Fatah. Fatah sebenarnya organisasi yang beraliran marxisme, dan sebelumnya sudah menyerap aspirasinya pada revolusi Aljazair. Mereka yang bergabung dalam Fatah (Harakah Tahrir Filistin dan kemudian menjadi Harakah at-Tahrir al-Wathani al-Filisthini) dideklatasi pertama di Kuwait pada 1957. Khalil al-Wazir (Abu Jihad), berasal dari Jalur Gaza, merupakan orang kedua dalam gerakan ini selama 30 tahun. Orang pertama dalam gerakan pembebasan adalah Pemuda IM Palestina.

\section{Organisasi Pembebasan Palestina}

Organisasi ini muncul pertama atas prakarsa Presiden Liga Arab Jamal Abdul Naser, yang melihat banyak aktivitas rahasia dalam rang pembebasan Palestina. Oleh karenanya pada 1959, dalam persidangan Liga Arab menyerukan adanya wadah bersatu perjuangan Palestina, dan menunjuk Ahmad Hilmi Abdul Baqi sebagai ketua OPP sekalaigus representasi pemerintahan rakyat Palestina. Hanya saja tahun 1963 ia meninggal dunia, dan dengan prakarsa Abd al-Naser terpilih pula Ahmad al-Syaqiri sebagai pengganti. Ia ditugaskan untuk mengorganisir masyarakat, memecahkan permasalahan dan mengaktifkan rakyat Palestina untuk perjuangan kesatuan negara bangsanya.

OPP dengan dukungan Mesir, berhasil eksis dan membentuk Majlis Nasional Palestina yang kemudian mengadakan konferensi pertamanya di kota al-Quds pada 28 Mei 1964 dengan dihadiri oleh 422 delegasi, representasi masyarakat Palestina, dengan pembinaan Raja Husein dari Yordania. Pada Konferensi ini dilegalkan OPP dengan Piagam Nasional Palestina, yang menegaskan bahwa perjuangan bersenjata untuk memerdekakan Palestina serta tidak mundur sejengkal pun dari tanahnya. Pada kesempatan itu juga dibentuk pasukan pembebasan Palestina dan upaya-upaya mobilisasi dan informasi ditingkatkan. ${ }^{27}$ Kenyataan

\footnotetext{
${ }^{26}$ Shaleh, The Palestinian Issue, h. 79.

${ }^{27}$ Ibid., h. 85-86.
} 
itu pula yang meningkat perjuangan Palestina dan direspon serius oleh Israel, Inggris dan Prancis selaku sekutu utamanya.

PLO atau OPP, ketika Yasser Arafat memimpin sejak tahun 1969, kepribadian nasional Palestina semakin mendapat tempat di hati rakyatnya dan masyarakat Islam umumnya menaruh harapan besar. Kemudiaan sejak Oktober tahun 1974OPP/PLO mendapat pengakuan negara-negara Arab sebagai organisasi tunggal rakyat Palestina yang legal. Bulan November tahun yang sama OPP membuat prestasi politis, ketika Yasser Arafat mendapat kesempatan untuk memberikan pidatonya di depan PBB di New York dan OPP/PLO diterima sebagai aanggota pengawas. Kemudian pada tahun itu juga Palestina mendapat klausul tersendiri di dalam persidangan PBB yang pertama kalinya. Salah satu resolusi terpenting PBB adalah resolusi 3236 yang dikeluarkan tanggal 22 November 1975 dengan judul resolusi hakhak bangsa Palestina, yaitu untuk menentukan masa depan mereka, hak merdeka dan berdaulat, hak kembali ke negerinya, hak untuk mengembalikan hak-hak fundamentalnya dengan segala cara sesuai tujuan piagam PBB. ${ }^{28}$

\section{Gerakan Hamas}

Hamas berdiri pada 14 Desemer 1987, merupakan faksi yang paling dinamis dan efektif. Ia merupakan sayap dan perpanjangan tangan dari gerakan Ikhwanul Muslimin. Dalam piagamnya disebutkan bahwa organisasi ini "menganggap Islam sebagai jalannya, yang dijadikan sebagai sandaran ide, konsepsi dan persepsi. Kepada Islamlah gerakan ini berhukum dan darinya meminta jalan keluar dalam perjalanannya". Di samping itu, Hamas mempunyai target "untuk memerdekakan bumi Palestina, mendirikan negara Islam di sana, dan menyerukan pendidikan yang universal bagi generasi untuk mewujudkan tujuan-tujuan yang diidam-idamkan". ${ }^{29}$

Syaikh al-Intifadhah Ahmad Yasin adalah pemimpin utama Hamas. Untuk wilayah Gaza pemimpinnya adalah 'Abd al-'Azîz al-Rantisi, Mahmûd al-Zahad dan 'Abd al-Fatâh Dukhân. Untuk wilayah Tepi Barat, pimpinan Hamas yaitu Jamal Salîm, Hasan Yûsuf dan Jamal Natasyah. Di luar Palestina sebagai kepala biro politik adalah Khralid Mish'al. Dengan pemimpin yang demikian itu Hamas berupaya mewujudkan peperangan dan akan dilanjutkan oleh generasi sesudahnya dan suatu ketika nanti baru mewujudkan negara Palestina. Dengan target demikian itu pula Hamas menggoncangkan entitas Zionis Yahudi, walaupun sebelumnya sudah ada perjanjiandan kesepakatan antara Israel dengan OPP/ PLO berdirinya pemerintahan otonom bagi bangsa Palestina di Gaza dan Tepi Barat sejak 1994. Hamas berhasil membunuh 70 Yahudi dan 340 lainnya luka-luka dalam FebruariMaret 1996. Akan tetapi suatu keanehan, PLO/OPP malah bekerjasama dengan zionis

${ }^{28}$ Ibid., h. 90.

${ }^{29}$ Ibid., h. 104. 
yang termasuk Amerika Serikat menekan dan menyerang Hamas. Tokohnya seperti Khâlid Mish'al ditangkap di Amerika dan Khâlid Mish'al menerima percobaan pembunuhan.

\section{Penutup}

Satu realitas yang nyata berwujud kini dan bahkan mendatang, Palestina semakin terpuruk dalam berhadapan dengan Yahudi Israel, sementara perhatian dan bantuan dari negara-negara Islam semakin sulit didapatkan karena sesama negara Islam sendiri dalam keadaan lemah dan suka berpecah belah antar negara dan dalam negara Islam sendiri, misalnya sebut saja Mesir, Suriah, Irak, Yaman dan seterusnya. Sementara Yahudi Israel semakin solid dan kuat dalam perekonomian, persenjataan dan mendapat dukungan pula secara terus menerus dari Negara-negara Besar seperti Amerika Serikat, Inggris, dan Prancis. Migrasi Yahudi dunia ke Israel juga bertambah pantastis. Tahun 1948 ketika berdiri Israel penduduknya yang Yahudi 650.000 orang dan tahun 2000 bertambah menjadi 4.947.000 orang.

Kemudianjika disahkannya RUU Yahudiyang sudah diajukan oleh Benyamin Netanyahu ke Parlemen Israel, maka ada kemungkinan penambahan Yahudi lebih signifikan dari sebelumnya, akan berlangsung migrasi Yahudi dunia besar-besaran dari berbagai Negara Eropa dan Amerika, sebab konsekwensi dari undang-undang baru Negara Zionis tersebut bahwa hanya orang Yahudi saja yang boleh menjadi warga Negara Israel. Sementara selainnya, Arab Islam yang sudah menjadi warga Negara Israel sekalipun selama ini yang mencapai dua juta jiwa lebih, atau seperempat penduduk Israel, diprediksi akan dikeluarkan dari kewarganegaraannya. Nama Negara Israel pun akan resmi berubah menjadi Negara Yahudi.

RUU dimaksud bagi Muslim Arab sebagai komunitas minoritas, diasumsikan menjadi gelisah dan berada di ujung tanduk, karena ada kemungkinan akan didepak oleh pemerintahan Israel yang Yahudi, jika RUU perubahan nama Negara Israel menjadi Negara Yahudi berhasil disahkan. ${ }^{30}$ RUU yang diajukan pemerintah Perdana Menteri Benjamin Netanyahu dan telah mendapat persetujuan kabinetnya dimaksud, mengantarkan Yahudi sebagai bangsa dan agama, memiliki semangat dan solidaritas baru di dunia internasional. Yahudi lebih luas maknanya dari Israel dan Ibrani. Hal itu karena istilah Yahudi selain disematkan kepada kaum Ibrani, juga bermakna dan dapat disematkan kepada orang-orang nonIbarani yang memeluk agama Yahudi. ${ }^{31}$ Sementara orang-orang keturunan Arab yang Islam semakin terdesak dengan kebijakan-kebijakan mengikat dan akanmengurangi atau ada kemungkinan akan hilang haknya di negerinya sendiri sebelumnya.

Seiring dengan kenyataan demikian dan jika RUU Israel diberlakukan maka kondisi

${ }^{30}$ Serambi Indonesia, Kamis, 27 November 2014, h. 2.

${ }^{31}$ Agha, Yahudi: Catatan Hitam Sejarah, h. 12. 
umat Islam bertambah diperburuk, dan Palestina sendiri khususnya, di samping kondisinya belum bersatu, banyak kelompok dan paksi ditambah pula harus menerima beban baru yaitu eksodus dan deportasi Muslim bekas kewarganegaraan Israel. Semua diprediksi berlangsung dalam waktu dekat.

Permasalahan yang sedang dan akan dihadapi Palestina idealnya harus menjadi merasa bahagian dari permasalahan umat Islam pada umumnya. Rasa persaudaraan Islam yang tumbuh dan berkembang di manapun umat Islam berada, menjadi alternative utama dalam pemecahan masalah umat Islam dan Negara Palestina hari ini dan di masa datang amas sukses mnggonvHamas menggoncangkan entitas Yahudi

\section{Pustaka Acuan}

Al-Thail, Abdullah. Yahudi Sang Penghancur Dunia, terj. Misbah Em Madjidy. Jakarta Timur: Mihrab, 2008.

Shibel, Fuad Muhammad. Masalah Jahudi International, terj. Bustami A. Gani dan Chatibul Umam. Djakarta: Bulan Bintang, 1970.

Cattan, Henry. Palestine and International Law. London: Longman, 1973.

Agha, Mahir Ahmad. Yahudi: Catatan Hitam Sejarah, terj. Yadi Indrayadi. Jakarta Timur: Qisthi Press, Juni 2005.

Nor, Mohd. Roslan Mohd. "Konflik Israel-Palestin dari Aspek Sejarah Modern dan Langkah Pembebasan dari Cengkaman Zionis," dalam Journal of Tamaddun, Desember 2010.

Shaleh, Muhsin Muhammad. Palestina: Sejarah, Perkembangan dan Konspirasi, terj. Tim Comes. Jakarta: Gema Insani Press, 2002.

Serambi Indonesia, Kamis, 27 November 2014. 